\title{
RESPONSE OF DIFFERENT CULTIVARS OF RADISH (RAPHANUS SATIVUS L.) TO ALTERNARIA LEAF SPOT ON SEED PRODUCTION DURING WINTER AT RUPANDEHI NEPAL
}

\author{
Madhu Sudhan Ghimire*, Prativa Khanal, Ambika Pokhrel, Jyotsna Nepal, Pramod Thagunna, Kanhaiya Prasad \\ Singh and Laxman Aryal \\ Institute of Agriculture and Animal Sciences, Nepal \\ ${ }^{*}$ Corresponding author email: madhusudhang48@gmail.com
}

\begin{abstract}
A field experiment was laid out in randomized complete block design with three replications and seven cultivars of Radish as treatments for screening against Alternaria leaf spot for seed production. Disease scoring was done as percentage of leaf area infected on individual plant at 7 and 10 days intervals on leaf and siliqua respectively for 3 times, and disease severity and mean AUDPC were calculated and yield was recorded. Disease symptoms appeared first in Long Chetki 22 DAS and last in Green Neck Miyashige 38 DAS. Maximum mean AUDPC (886.7) on foliage was recorded in Long Chetki while minimum mean AUDPC (690.7) was recorded in Green Neck Miyashige Similarly, highest and lowest total mean AUDPC on siliqua were seen on cultivars 40 Days (1080) and Green Neck Miyashige (66.67) respectively. Highest yield was recorded in Green Neck Miyashige (695.2kg/ha) and lowest yield was recorded in cultivar Long Chetki (477.4kg/hac). Similarly, highest test weight was recorded in cultivar Mino Early (10.28gm) and lowest was recorded in cultivar 40-Days (8.4gm). Cultivar, All Season Green Long failed inflorescence formation hence no evidence of siliqua formation therefore bears value 0 for seed yield. Similarly, highest biomass yield excluding root was found in cultivar Subhra-32 $\left(613.3 \mathrm{gm} / \mathrm{m}^{2}\right)$ and lowest biomass yield was recorded in cultivar Green Neck Miyashige $\left(341.7 \mathrm{gm} / \mathrm{m}^{2}\right)$. Green Neck Miyashige was found resistant to Alternaria leaf spot disease with maximum seed yield (695.2kg/ha). The cultivars Subhra-32 and 40 days were highly susceptible to Alternaria leaf spot disease with minimum seed yield.
\end{abstract}

Keywords: Alternaria leaf spot; AUPDC; Radish; Screening; Siliqua

\section{Introduction}

Radish (Raphanus sativus L.), one of the most popular root vegetable crops, can successfully be grown throughout the year in the hills of Nepal (Poon et al., 2004). Its popularity could be due to its wider climatic adaptation, easy cultivation methods and wider ranges of uses (Shrestha and Shakya, 2004). Area under radish was about 16,570 ha and total production was 2, 19,230 tons with an average productivity of $13.23 \mathrm{t} \mathrm{ha}^{-1}$ in Nepal (VDD, 2009).

The major factors responsible for low production of cucurbitaceous, brassicaceous and solanaceous vegetables are the diseases caused by Alternaria. The blights are serious destroyers and disease development is so fast that whole crop is lost in a few days. Therefore, the problem deserves immediate and effective measures of control (Verma and Verma, 2010).

Crucifers encounter number of foliar diseases among them Alternaria blight is the most devastating causing yield loss of 35-38\% (Kolte et al., 1987). In addition to the direct losses in yield, the disease adversely affects seed quality by reducing seed size, seed discoloration and reduction in oil content (Prasad and Lallu, 2006). The disease also reduces germination ability, oil content and protein content of seeds. In the absence of resistant donor germplasm of mustard, plant breeding approaches for the development of novel resistant genotypes are still remain questionable. The most practical way to overcome this situation to understand the internal built resistance in the plants. Plants challenged by fungal pathogen exhibit several biochemical defense responses which include accumulation of specific metabolites (Daayf et al., 2000).

The crop is severely affected by Alternaria blight caused by Alternaria raphani during both seed and root crop production. All foliage is full of small, circular spots and very destructive at siliqua formation stage where all floral part, pods peduncle and seeds become black. Most of pods are devoid of seed, shriveled seeds and fail to germinate in next year. This disease is internally seed borne where pathogen infects pericarp and cotyledon of the seeds (Atkinson, 1949). 
Alternaria blight diseases of crop plants have been reported from all the continents of the world, cause average loss of 5-47\% in India (Kolte, 1985; Kolte et al., 1987; Sharma and Kolt, 1994); 5\% in Canada (Tewari, 1991); 57\% in Nepal (Shrestha et al., 2005)

There are no recommended varieties of radish resistant to Alternaria leaf blight for seed production in terai region of Nepal. (DADO Rupandehi, 2014)

\section{Materials and Methods}

\section{Experimental Site}

A field experiment was conducted at Siddharthanagar Rupandehi, Nepal (27 $32^{\prime \prime} \mathrm{N}, 83^{\circ} 25^{\prime \prime} \mathrm{E}$ and 105 masl) during winter (January -April, 2015) under partially irrigated conditions. The soil type is clay loam and climatically humid sub-tropical with average annual rainfall of 2000 $\mathrm{mm}$.

\section{Treatments}

Commonly cultivated 7 different radish varieties in Nepal: Pyuthane Rato, Green Neck Miyashige, Subhra 32, All Season Green Long, Mino Early, 40 Days and Long Chetki were used as treatments for screening against Alternaria leaf blight.

\section{Experimental Setup}

The experiment was conducted in a randomized complete block design with 7 treatments replicated thrice. Individual plot size was $1 \mathrm{~m}^{2}(1 \mathrm{~m} \mathrm{x} 1 \mathrm{~m})$. There were 5 rows of $1 \mathrm{~m}$ length per plot spaced $20 \mathrm{~cm}$ apart with plant to plant spacing of $20 \mathrm{~cm}$.

\section{Disease Assessment}

Disease incidence was recorded immediately after appearance of disease, and disease scoring was started 10 days after disease appearance. The disease estimation was based on a modified 0 to 5 scale given by Townsend and Heuberger (1943) as given below:

0- No symptoms

1- Small light brown spots scattered covering $\leq 5 \%$ leaf area.

2- Spots small, brown, with concentric rings, covering 5.1 to $10 \%$ leaf area.

3- Spots large, brown, irregular, with concentric rings, covering 10.1 to $25 \%$ leaf area.

4- Large, brown, irregular lesions with typical blight symptoms, covering 25.1 to $50 \%$ leaf area.

5- Large, brown, irregular lesions with typical blight symptoms, covering more than 50\% leaf area

The percentage of disease for each plot was calculated using the formula of Townsend and Heuberger (1943) as,
$\mathrm{P}=\frac{\sum(n \times v)}{5 N} \times 100$, where, $\mathrm{P}=$ disease percent, $\mathrm{n}=$ number of plants in each index, $v=$ numerical value of each index, $\mathrm{N}=$ total number of plants.

AUDPC was calculated according to the formula suggested by Ceballos et al. (1991) and Forbes et al. (1993) as given below:

$$
A_{k}=\sum_{i=1}^{N_{i}-1} \frac{\left(y_{i}+y_{i+1}\right)}{2}\left(\mathrm{t}_{i+1}-\mathrm{t}_{i}\right)
$$

Where, $A_{k}=$ AUDPC at $k^{\text {th }}$ observation, $\mathrm{i}=1, Y_{i}=$ disease index (per unit) at $\mathrm{i}^{\text {th }}$ observation, $\mathrm{X}_{\mathrm{i}}=$ time (day) and $\mathrm{N}=$ total number of observations, $\mathrm{t}_{\mathrm{i}}=$ first date of disease scoring

AUDPC per day was calculated to find out the daily progress of disease dividing the total AUDPC by days interval between the two disease scoring dates.

\section{Crop Yield Parameters Assessed}

Thousand seed weight, total biomass yield, total seed yield and number of seeds per 50 siliqua were taken.

\section{Statistical Analysis}

The data were analyzed using MSTAT-C (Freed and Scott, 1986). ANOVA and DMRT were done at $1 \%$ and $5 \%$ level of significance for mean comparison from the reference of Gomez and Gomez (1984). Correlation and regression analysis were done for group comparison (Gomez and Gomez, 1984).

\section{Results and Discussion}

\section{Disease Incidence on Foliage}

Symptoms of Alternaria leaf spot disease was first observed on cultivar 40 Days (24 DAS) followed by cultivar Long Chetki (27 DAS). Cultivar Green Neck Miyashige was infected at last i.e. 32 DAS. Similarly Disease incidence percentage was seen highest $(93.33 \%)$ in cultivar 40 Days followed by cultivar Long Chetki recording (93.06\%.) Lowest disease incidence percentage $(65.33 \%)$ was seen on cultivar Green Neck Miyashige as shown in Fig. 1.

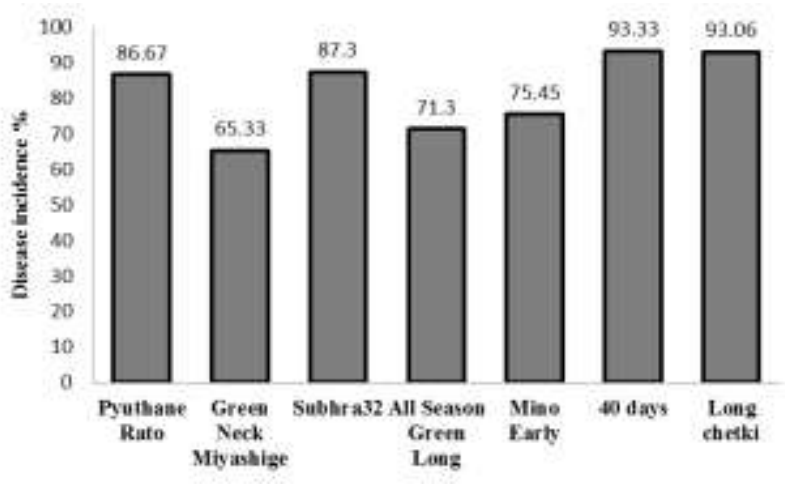

Fig. 1: Graph showing percentage disease incidence of 7 different radish cultivars 


\section{AUDPC on Foliage}

AUDPC on foliage were calculated as total and per day AUDPC values. The cultivars varied significantly in AUDPC values in all 3 observation dates. AUDPC values increased with time of observation in all the cultivars. Highest and lowest values of total AUDPC and AUDPC per day were seen on cultivars Long Chetki and Green Neck Miyashige respectively.

Cultivars Long Chetki (63.33) and 40 Days (63.00) did not differ significantly for mean values of AUDPC per day and were found highly susceptible to Alternaria leaf spot. Also Pyuthane Rato with AUDPC per day (57.67) was found to be highly susceptible to Alternaria leaf spot. Similar result was found by (Gautam, 2007).Similarly cultivars Green Neck Miyashige (49.33) and All Season Green Long (50.00) are similar for mean values of AUDPC per day (Table 1).

\section{Disease Incidence on Siliqua}

Disease incidence on siliqua occurred first (79.33 DAS) on the cultivars Subhra - 32 and 40 Days. Similarly cultivar
All Season Green Long failed bolting hence no evidence of siliqua and subsequently no disease incidence on siliqua. Disease incidence on siliqua was observed last (82.67 DAS) on cultivar Green Neck Miyashige (Fig. 2).

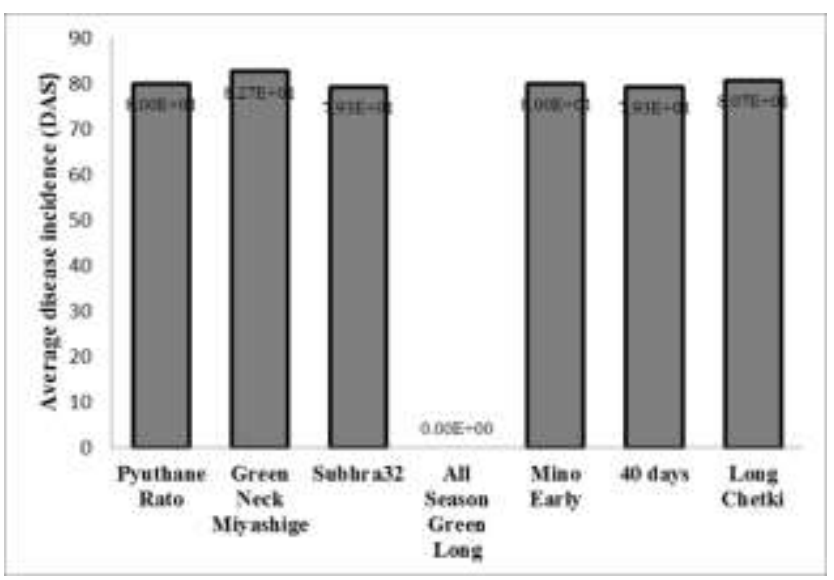

Fig. 2: Number of days to disease incidence on siliqua

Table 1: Mean AUDPC values (foliage) on 7 different Radish cultivars during January to April, 2015 at Paklihawa, Bhairahawa

\begin{tabular}{|c|c|c|c|c|}
\hline S.N. & Treatments & $\begin{array}{l}\text { Total AUDPC } \\
\text { (foliage) }\end{array}$ & AUDPC Per Day (foliage) & Resistance Category \\
\hline 1. & Pyuthane Rato & $807.3^{\mathrm{ABC}}$ & $57.67^{\mathrm{ABC}}$ & HS \\
\hline 2. & Green Neck Miyashige & $690.7^{\mathrm{C}}$ & $49.33^{\mathrm{C}}$ & MR \\
\hline 3. & Subhra 32 & $868.0^{\mathrm{AB}}$ & $62.00^{\mathrm{AB}}$ & HS \\
\hline 4. & All Season Green Long & $700.0^{\mathrm{C}}$ & $50.00^{\mathrm{C}}$ & MR \\
\hline 5. & Mino Early & $714.0^{\mathrm{BC}}$ & $51.00^{\mathrm{BC}}$ & S \\
\hline 6. & 40 Days & $882.0^{\mathrm{A}}$ & $63.00^{\mathrm{A}}$ & HS \\
\hline 7. & Long Chetki & $886.7^{\mathrm{A}}$ & $63.33^{\mathrm{A}}$ & HS \\
\hline & $\operatorname{SEm}( \pm)$ & 47.96 & 3.426 & \\
\hline & $\operatorname{LSD}(0.050)$ & 147.8 & 10.56 & \\
\hline & $\mathrm{CV} \%$ & 10.48 & 10.48 & \\
\hline & Probability & $0.0317 *$ & $0.0317^{*}$ & \\
\hline
\end{tabular}

AUDPC: Area Under Disease Progression Curve, R: Resistant, MR: Moderately Resistant, S: Susceptible, HS: Highly Susceptible, CV: Coefficient of Variation, LSD: Least Significant Difference. Means followed by the same letters in a column are not significantly different by DMRT at $5 \%$ level of significance; SEm $( \pm)$ indicates standard error of mean. 


\section{AUDPC on Siliqua}

AUDPC on siliqua were calculated as total and per day AUDPC values. The cultivars varied significantly on AUDPC values in all 3 observation dates spaced at the interval of 10 days. AUDPC values increased with time of observation in all the cultivars. Highest and lowest total AUDPC and AUDPC per day values were seen on cultivars 40 Days and All Season Green Long respectively. But the cultivar All Season Green Long failed bolting hence no evidence of siliqua formation therefore bears value (0.000) for Total and per day AUDPC value which has no significance. Subsequently, lowest total and per day AUDPC was observed on cultivar Green Neck Miyashige. Cultivars 40 Days (54.00) and Subhra - 32 (49.00) did not differ significantly for mean values of AUDPC per day (Table 2).

\section{Test Weight and Total Seed Yield}

Seed yield varied significantly among the cultivars. Maximum seed yield was recorded Green Neck Miyashige
$(695.2 \mathrm{~kg} / \mathrm{ha})$ and lowest mean total yield was recorded in cultivar Long Chetki (477.4kg/hac). However, the yield of Green Neck Miyashige (695.2kg/ha) and Subhra - 32 $(680 \mathrm{~kg} / \mathrm{ha})$ did not differ significantly. Maximum test weight was recorded in cultivar Mino Early (10.28gm) followed by cultivar Green Neck Miyashige (9.073gm) and least was recorded in cultivar 40-Days (8.4gm). However, test weight of cultivar 40-Days $(8.4 \mathrm{gm})$ and cultivar Pyuthane Rato $(8.64 \mathrm{gm})$ did not differ significantly (Table3).

Similarly, highest biomass yield excluding root was found in cultivar Subhra-32 $\left(613.3 \mathrm{gm} / \mathrm{m}^{2}\right)$ and lowest biomass yield was recorded in cultivar Green Neck Miyashige $\left(341.7 \mathrm{gm} / \mathrm{m}^{2}\right)$. However, biomass yield of Subhra$32\left(613.3 \mathrm{gm} / \mathrm{m}^{2}\right)$, Green Neck Miyashige $\left(586 . \mathrm{gm} / \mathrm{m}^{2}\right)$, Mino Early $\left(580 \mathrm{gm} / \mathrm{m}^{2}\right)$, 40Days $\left(573.3 \mathrm{gm} / \mathrm{m}^{2}\right)$ and Pyuthane Rato $\left(525 \mathrm{gm} / \mathrm{m}^{2}\right)$ did not vary significantly (Table 3).

Table 2: Mean AUDPC values (Siliqua) of 7 Radish cultivars

\begin{tabular}{|r|l|l|l|l|}
\hline S.N. & Treatments & Total AUDPC (siliqua) & AUDPC per day (siliqua) & Resistant Category \\
\hline 1. & PyuthaneRato & $386.7^{\mathrm{C}}$ & $19.33^{\mathrm{C}}$ & $\mathrm{MR}$ \\
\hline 2. & Green Neck Miyashige & $66.67^{\mathrm{D}}$ & $3.333^{\mathrm{D}}$ & $\mathrm{R}$ \\
\hline 4. & Subhra 32 & $980.0^{\mathrm{A}}$ & $49.00^{\mathrm{A}}$ & $\mathrm{HS}$ \\
\hline 5. & Mino Early & $0.0000^{\mathrm{D}}$ & $0.0000^{\mathrm{D}}$ & - \\
\hline 6. & 40 Days & $360.0^{\mathrm{C}}$ & $18.00^{\mathrm{C}}$ & $\mathrm{MR}$ \\
\hline 7. & Long Chetki & $1080.0^{\mathrm{A}}$ & $54.00^{\mathrm{A}}$ & $\mathrm{HS}$ \\
\hline & SEm $( \pm)$ & $766.7^{\mathrm{B}}$ & $38.33^{\mathrm{B}}$ & $\mathrm{S}$ \\
\hline & LSD $(0.010)$ & 38.38 & 1.919 & \\
\hline & CV\% & 165.8 & 8.290 & \\
\hline & Probability & $0.0000^{* *}$ & $0.0000^{* *}$ & \\
\hline
\end{tabular}


Table 3: Test weight $(\mathrm{gm})$, Total seed yield $(\mathrm{Kg} / \mathrm{ha})$ and biomass $\left(\mathrm{gm} / \mathrm{m}^{2}\right)$ on 7 radish cultivars

\begin{tabular}{|c|c|c|c|c|}
\hline S.N. & Treatments & Test Weight (gm) & $\begin{array}{l}\text { Total Seed Yield } \\
\text { (kg/ha) }\end{array}$ & Biomass $\left(\mathrm{gm} / \mathrm{m}^{2}\right)$ \\
\hline 1. & Pyuthane Rato & $8.64^{\mathrm{ABC}}$ & $521.9^{\mathrm{D}}$ & $525.0^{\mathrm{A}}$ \\
\hline 2. & Green Neck Miyashige & $9.073^{\mathrm{AB}}$ & $695.2^{\mathrm{A}}$ & $586.7^{\mathrm{A}}$ \\
\hline 3. & Subhra-32 & $9.8^{\mathrm{AB}}$ & $680^{\mathrm{A}}$ & $613.3^{\mathrm{A}}$ \\
\hline 4. & All Season Green Long & $0^{\mathrm{D}}$ & $0^{\mathrm{F}}$ & $341.7^{\mathrm{B}}$ \\
\hline 5. & Mino Early & $10.28^{\mathrm{A}}$ & $606.2^{\mathrm{C}}$ & $580.0^{\mathrm{A}}$ \\
\hline 6. & 40 Days & $8.4^{\mathrm{ABC}}$ & $635.1^{\mathrm{B}}$ & $573.3^{\mathrm{A}}$ \\
\hline 7. & Long Chetki & $9.413^{\mathrm{AB}}$ & $477.4^{\mathrm{E}}$ & $451.7^{\mathrm{AB}}$ \\
\hline & $\operatorname{SEm}( \pm)$ & 0.4476 & 6.634 & 36.45 \\
\hline & $\operatorname{LSD}(0.010)$ & 1.933 & 28.66 & 157.5 \\
\hline & $\mathrm{CV} \%$ & 9.15 & 19.48 & 12.04 \\
\hline & Probability & $0.000 * *$ & $0.000 * *$ & $0.0022^{* *}$ \\
\hline
\end{tabular}

DMRT at $1 \%$ level of significance

\section{Regression Analysis}

In a unit increase in days to disease incidence (DAS) on foliage, mean total AUDPC of foliage have decreased by 15.67 times. According to coefficient of determination, about $78.7 \%$ variation in mean total AUDPC on foliage was due to days to disease incidence on foliage as in Fig. 3.

There was a significant $(\mathrm{P} \leq 0.01)$, negative, linear relationship between mean total AUDPC of foliage to test weight $(\mathrm{gm})$ and Mean total seed yield $(\mathrm{kg} / \mathrm{ha})$. In a unit increase in mean total AUDPC on foliage, mean test weight $(\mathrm{gm})$ and mean total seed yield $(\mathrm{kg} / \mathrm{ha})$ have decreased by 0.003 and 0.368 times respectively. $14.9 \%$ and $13.5 \%$ variation in mean value of test weight (gm) and mean total seed yield $(\mathrm{kg} / \mathrm{ha})$ was due to total AUDPC on foliage (Fig. 4).

There was a significant $(\mathrm{P} \leq 0.01)$, negative, linear relationship between mean total AUDPC on siliqua to Mean total seed yield (kg/ha) and mean test weight (gm). According to linear regression equation in an unit increase in mean total AUDPC on siliqua, mean total seed yield( $\mathrm{kg} / \mathrm{ha})$ and mean test weight(gm) have decreased by 0.011 and 0.000 times respectively. According to the coefficient of determination, about $0.2 \%$ and $1.9 \%$ variation in mean total seed yield $(\mathrm{kg} / \mathrm{ha})$ and mean value of test weight (gm) was due to total AUDPC on siliqua and remaining portion was due to other factors (Fig. 5).

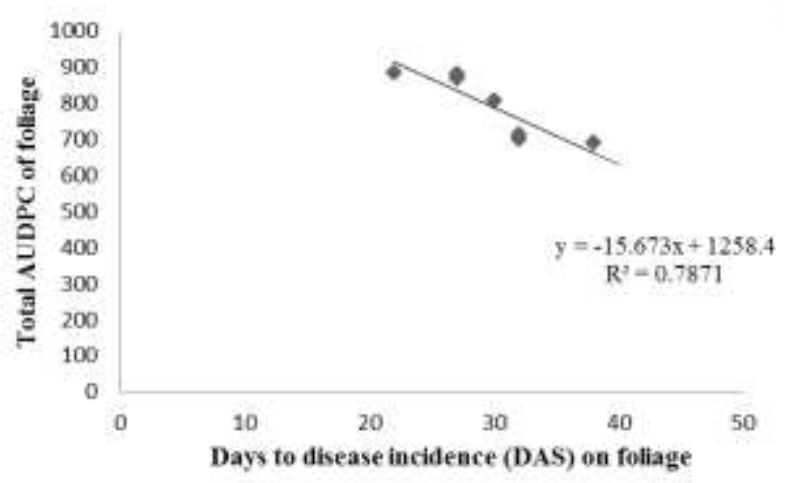

Fig. 3: Linear relationship between days to disease incidence DAS on foliage and total AUDPC of foliage 

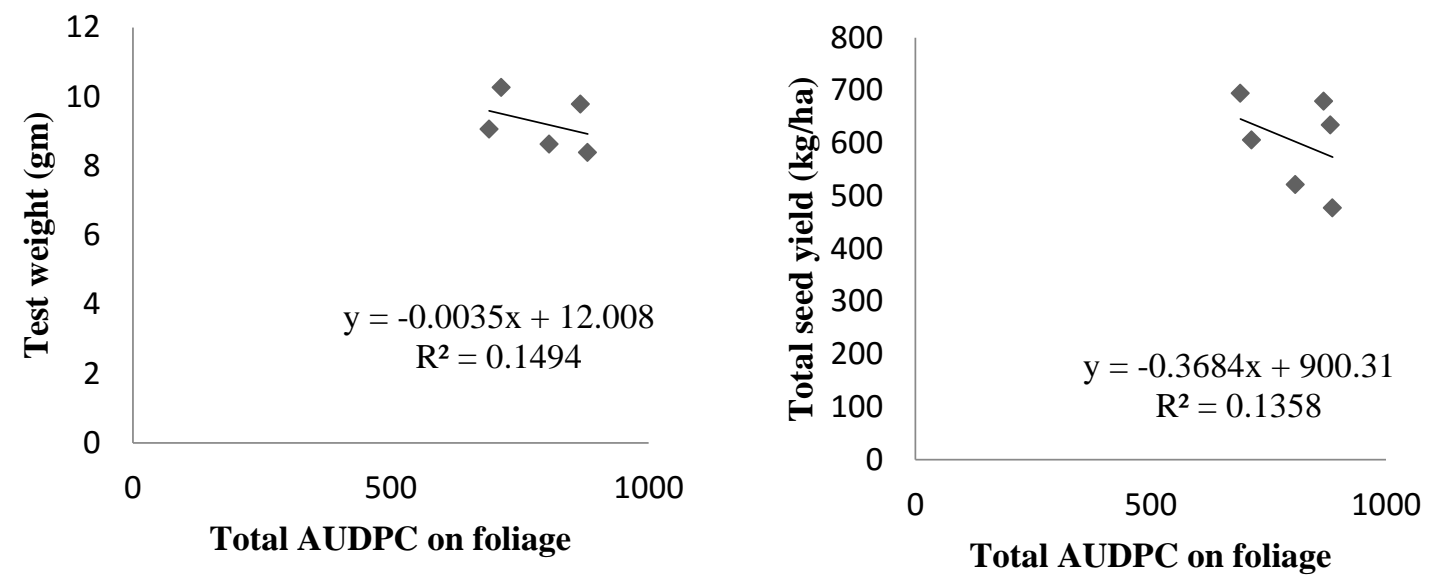

Fig. 4: Linear relationship between total AUDPC on foliage with test weight (gm) and total seed yield (kg/ha)
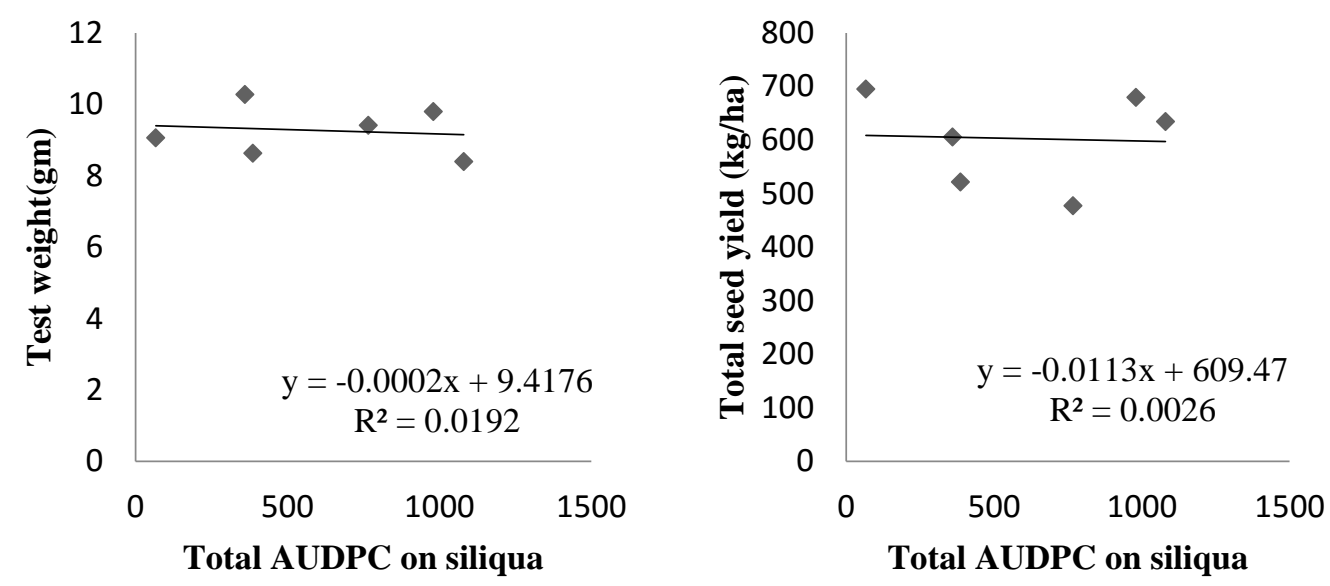

Fig. 5: Linear relationship between total AUDPC on siliqua with test weight (gm) and total seed yield $(\mathrm{kg} / \mathrm{ha})$

The performance of radish cultivars varied significantly with Alternaria leaf spot disease. Screening of cultivars seemed to be one of the important techniques for finding the source of resistant and susceptible cultivars. Cultivar Green Neck Miyashige was found to be resistant to Alternaria leaf spot disease with maximum seed yield ( $\mathrm{kg} / \mathrm{ha})$. These cultivars could be used as source of resistant varieties in breeding programs. The cultivars Subhra-32 and 40 days were highly susceptible to Alternaria leaf spot disease with minimum seed yield ( $\mathrm{kg} / \mathrm{ha}$ ). These cultivars can be used as susceptible check for breeding purpose and different varietal screening Programs. Also, Seed production of Green Neck Miyashige cultivar during winter at Terai region of Nepal was found to be feasible with significantly high seed yield. Thus this variety can be used for seed production purpose in Terai during winter.

\section{Acknowledgement}

The authors are thankful to Tribhuuvan University, Institute of Agriculture and Animal Sciences, Paklihawa Campus for the support and cooperation during the research. Also we are thankful to the students there for assistance in field works.

\section{References}

Atkinson RG (1949) Seed-borne disease of radish caused by Alternaria Raphani.

Daayf F, Ongena, M, Boulanger R, Hadrami IE and Belanger RR (2000) Induction of phenolic compounds in two cultivars of cucumber by treatment of healthy and powdery mildewinfected plants with extracts of Reynoutria sachalinensis. J. Chem. Ecol. 26: 1579-1593. DOI: 10.1023/A:1005578510954

DADO Rupandehi (2014) Annual Report (2071/072), District Agriculture Development Office, Rupandehi Nepal.

Gomez KA and Gomez AA (1984) Statistical procedures for agricultural research. John Wiley \& Sons.

Kolte SJ (1985) Diseases of Annual Edible Oilseed Crops, Rapeseed-mustard and Sesame Diseases. CRC Press Inc., N.W., Boca Raton FL, USA. 2: 127. 
Kolte SJ, Awasthi RP and Vishwanath (1987) Assessment of yield losses due to Alternaria blight in rapeseed and mustard. Indian Phytopathol. 10: 209- 211.

Poon TB, Regmi HN and Woli OB (2004) Influence of plant spacing on seed yield of radish Mino Early. In: Khatri BB, Sharma BP, Khatiwada PP, Paudyal KP, Khadge BR and Regmi HN (Eds) Proceedings of the fourth national workshop on horticulture (2-4 March 2004). Nepal Agricultural Research Council, Khumaltar. 373-376.

Prasad R and Lallu (2006). Management of Alternaria blight of mustard with combination of chemicals and botanicals. Ann. Pl. Protec. Sci. 14:2 400- 403.

Sharma SR and Kolte SJ (1994) Influence of nutritional factors on phytotoxic effects of Alternaria brassicae. Indian Phytopathol. 47: 186- 187.

Shrestha MM and Shakya SM (2004) Response of radish crop var. fourty days to transplanting age and detopping in respect to seed yield. In: Khatri BB, Sharma BP, Khatiwada PP, Paudyal KP, Khadge BR and Regmi HN (Eds) Proceedings of the fourth national workshop on horticulture (2-4 March 2004). Nepal Agricultural Research Council, Khumaltar. 377-379

Shrestha SK, Munk L and Mathur SB. (2005) Role of weather on Alternaria Leaf Blight Disease and its effect on Yield and Yield Components of Mustard. Nepal Agric. Res. J. 6: 62 -72 .

Tewari JP (1991) Structural and biochemical bases of the black spot disease of crucifers. Adv. Struct. Biol. 1: $325-349$.

Townsend GK and Hunberger TW (1943) Methods for estimating losses caused by disease in fungicides experiments. Plant Dis. Reptr. 27: 340 - 343.

VDD (2009) Annual progress report (2065/2066). Vegetable Development Directorate, Agriculture Department, Ministry of Agriculture, Nepal. 89.

Verma N and Verma S (2010) Alternaria diseases of Vegetable Crops and New Approaches for its Control Botany Department, Feroze Gandhi College, Rae Bareli - 229001. Asian j. exp. biol. sci. 1: 681-692. 